\title{
The Leap of the Tiger: How Malaysia Can Escape the Middle-Income Trap
}




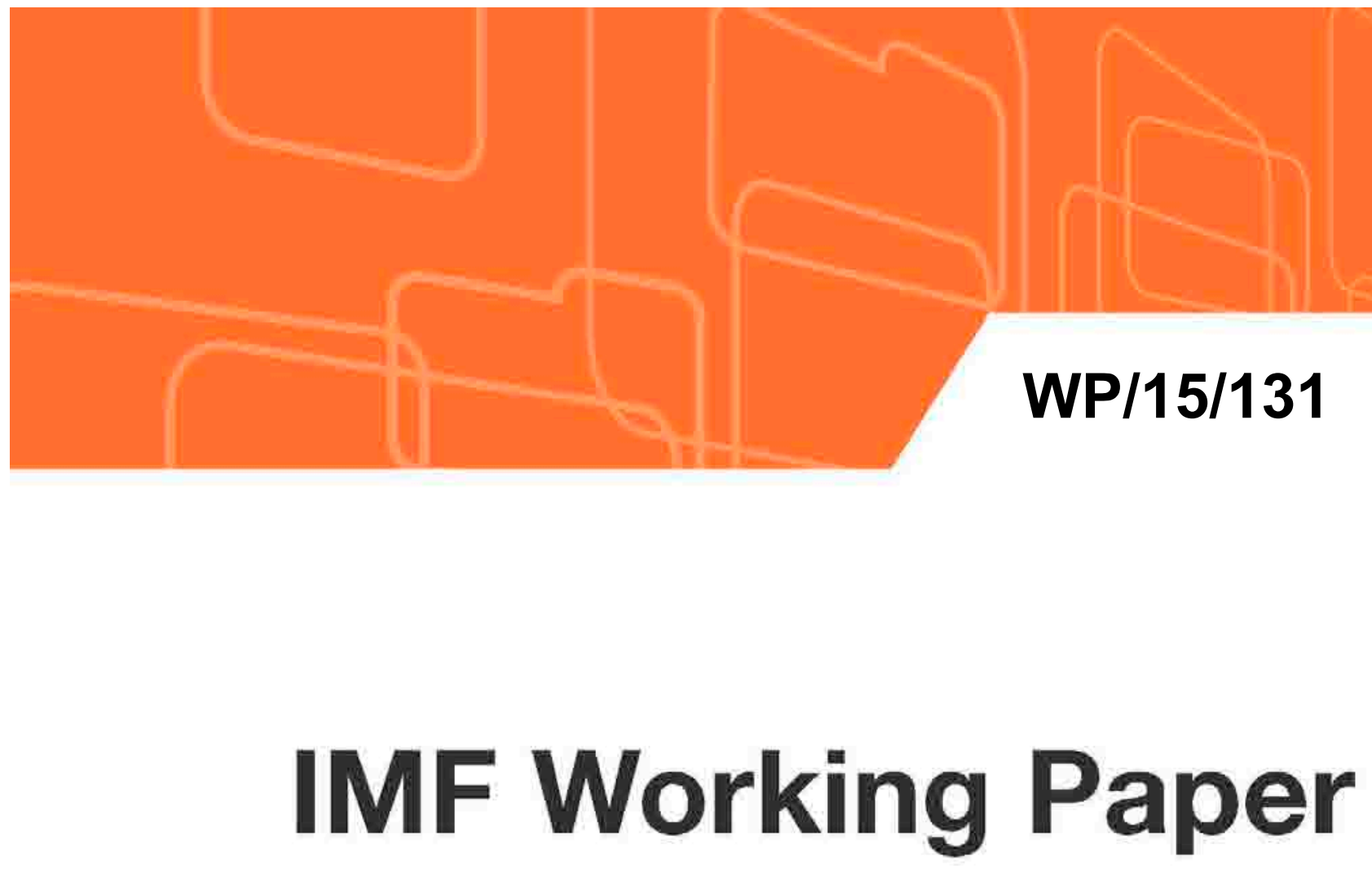

\section{The Leap of the Tiger: How Malaysia Can Escape the Middle-Income Trap}

by Reda Cherif and Fuad Hasanov

IMF Working Papers describe research in progress by the author(s) and are published to elicit comments and to encourage debate. The views expressed in IMF Working Papers are those of the author(s) and do not necessarily represent the views of the IMF, its Executive Board, or IMF management.
I $N$
N T E R N A T I O N A L
$M O N E T A R Y$
$F \cup N D$ 


\title{
IMF Working Paper
}

Institute for Capacity Development and Asia and Pacific Department

\section{The Leap of the Tiger: How Malaysia Can Escape the Middle-Income Trap Prepared by Reda Cherif and Fuad Hasanov ${ }^{1}$}

Authorized for distribution by Ray Brooks and Alex Mourmouras

June 2015

\section{IMF Working Papers describe research in progress by the author(s) and are published to elicit comments and to encourage debate. The views expressed in IMF Working Papers are those of the author(s) and do not necessarily represent the views of the IMF, its Executive Board, or IMF management.}

\begin{abstract}
Only a few European economies and Korea and Taiwan Province of China reached highincome status during 1970-2010. Malaysia's real income per capita increased to 26 percent of the U.S. level in 2010 from 20 percent in 1970. Despite relatively strong growth and a substantial improvement in export sophistication, Malaysia's total factor productivity lagged behind that of Korea and Taiwan Province of China. We argue that what characterizes their experience in contrast to Malaysia's is the creation of technologies by domestic firms and a push to leapfrog to the technological frontier at an early stage of development.
\end{abstract}

JEL Classification Numbers: O14, O25, O38, O40, O53

Keywords: growth, middle-income trap, innovation, productivity, technology

Author's E-Mail Address: acherif@imf.org; fhasanov@imf.org

\footnotetext{
${ }^{1}$ We are grateful to Ray Brooks, Amine Mati, Alex Mourmouras, Niamh Sheridan, Jojo Zhao, and seminar participants at Istanbul Technical University for valuable comments and discussions, and the Malaysian Productivity Corporation and Malaysia's Ministry of International Trade and Industry for helpful comments.
} 


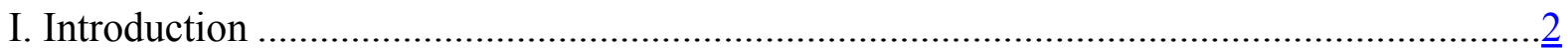

II. The Middle-Income Trap: Malaysia in Perspective ....................................................... $\underline{3}$

III. The Missing Link: Creating Own Technology ..........................................................

IV. Creating Own Technology: In the Footsteps of Taiwan Province of China and Korea .....13

V. Toward a High Productivity and High Linkages Economy .........................................17

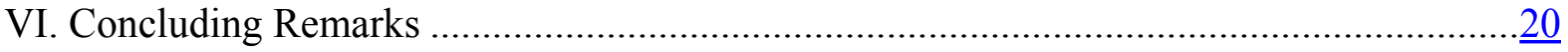

Figures

Figure 1. GDP per capita relative to the US (2005 PPP \$), 1970 vs. 2010 ............................ 4

Figure 2. Malaysia, Korea, and Taiwan Province of China: GDP per capita (2005 PPP \$), 1970-2010

Figure 3. Malaysia, Chile, and Thailand: GDP per capita (2005 PPP \$), 1970-2010 ..............

Figure 4. Malaysia, Korea, and Taiwan Province of China: TFP $(1970=100), 1970-2010 \ldots \ldots . . .6$

Figure 5. Malaysia, Chile, and Thailand: TFP $(1970=100), 1970-2010$.................................

Figure 6. Manufacturing Output per Worker, 1975-2005.............................................. $\frac{7}{9}$

Figure 7. Goods Export Sophistication (Constant 2000 PPP \$), 1976-2006 .........................

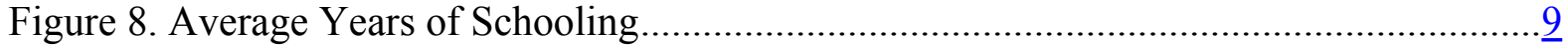

Figure 9. US Patents Granted, 1977-2013 ..................................................................... $\frac{10}{10}$

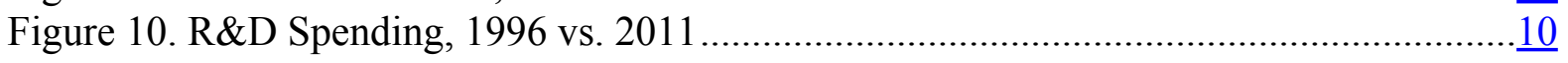

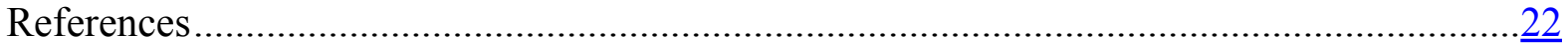




\section{INTRODUCTION}

For the past several decades, Malaysia has witnessed strong economic growth and has become one of the Asian newly industrialized countries. Gross domestic product (GDP) per capita grew by an average 2.8 percent per year over $1970-2010$, reaching $\$ 10,830$ per capita (in 2005 purchasing power parity, PPP, terms). ${ }^{2}$ Malaysia belongs to the upper-middle income group of countries according to standard classifications (e.g., World Bank). The country diversified its export base and increased export sophistication substantially. High growth increased the standard of living. Human development indicators improved significantly; average years of schooling increased; and infant mortality fell while life expectancy rose. Despite the overall good performance, crucial questions remain whether Malaysia can reach high-income status and which policies it needs to implement to succeed.

The cross-country experience indicates that the odds of reaching high-income status are low, highlighting the "middle-income trap" phenomenon. Using the definition of real income per capita relative to the US, only nine out of 167 economies in the sample in 2010-Cyprus, Czech Republic, Greece, Ireland, Korea, Malta, Portugal, Slovenia, and Taiwan Province of China - reached high-income status in the past 40 years. Furthermore, only two economies, which were below Malaysia's income in 1970, made it to high-income status: Korea and Taiwan Province of China. Given the historic record, escaping the "middle-income trap" would constitute an economic "miracle."3

Despite its strong growth and large improvement in export sophistication, Malaysia's total factor productivity has not grown as much as that of Korea and Taiwan Province of China. In addition, the country relied substantially on the multinational corporations and foreign direct investment for export upgrading and technological transfer. Despite persistent attempts to increase local content and export upgrading, the results, although tangible, remained limited. Technology creation and diffusion did not occur to the extent hoped for, and industry linkages and agglomeration were not widespread. Research indicates that in general, multinationals are not keen on transferring technology to other countries. The experiences of Korea and Taiwan Province of China, who mostly relied on creating technology by local firms, were much more successful in innovating and increasing productivity. Creating and diffusing technology through local firms are key to improving productivity and generating innovation and technological upgrading. Increasing research and development (R\&D) spending, improving education quality and increasing a share of science and engineering graduates, while pursuing policies that Korea and Taiwan Province of China used to create local firms and clusters in high-tech sectors are needed to break through the middle-income trap.

The structure of the paper is as follows. The next section defines the middle-income trap and examines Malaysia's economic performance in comparison with other economies such as Korea, Taiwan Province of China, Thailand, and Chile. The following section argues that the lack of domestic technological upgrading is the main reason Malaysia could not follow in the

\footnotetext{
${ }^{2}$ Penn World Tables 8.0.

${ }^{3}$ Based on the definition of the high-income threshold defined in the next section.
} 
footsteps of Taiwan Province of China and Korea. Then, key policies that Korea and Taiwan Province of China undertook to achieve their technological successes are examined. The section before last explores economic sectors needed for sustainable growth and pitfalls to avoid, while the last section concludes.

\section{The Middle-Income Trap: Malaysia in Perspective}

The "middle-income trap" is generally associated with the notion that countries get stuck in a certain range of income distribution and rarely manage to reach high-income status.

Although the range associated with middle-income status differs across studies, they are in general defined in absolute terms. The World Bank, for instance, defines income thresholds based on current gross national income (GNI) per capita with the upper middle-income threshold of \$4,125 and high-income threshold of \$12,746 for 2014. ${ }^{4}$ Felipe (2012) transforms current GNI per capita thresholds into those based on GDP per capita in constant PPP dollars and arrives at upper-middle and high-income range of about $\$ 7,250-\$ 11,750$ (1990 PPP). Using growth slowdown episodes, Aiyar et. al. (2013) define \$15,000 (2005 PPP) as the threshold for high-income countries. Eichengreen, Park, and Shin (2013) further conclude that the growth slowdowns occur at GDP per capita of $\$ 10,000-\$ 11,000(2005$ PPP) as well as of $\$ 15,000-\$ 16,000$. Overall, the definitions of the high income threshold as well as growth slowdowns of countries reaching that stage occur in the $\$ 11,000-\$ 15,000$ (2005 PPP) range.

This paper uses relative income to examine how countries fare in the cross-country income distribution and to define the middle-income range. The standard methods to define income status using absolute levels of income need to be updated regularly so as not to ignore the evolution of income in other countries. The goal of economic development is to reach the living standards of the most advanced countries today, and thresholds based on relative income capture how far an economy is from reaching that goal. The distribution of GDP per capita (2005 PPP dollars) relative to the US in 1970 is used as a benchmark. ${ }^{5}$ The uppermiddle income threshold, which we define with the median, is 16 percent of the US income per capita, while the high-income threshold, the $75^{\text {th }}$ percentile, is 46 percent (Figure 1$) .^{6}$ In 2010, the upper-middle income threshold was about $\$ 6600$, while the high-income threshold was about $\$ 19,050 .^{7}$ These figures raise the bar for the countries to escape the middle-income trap and reach high-income status. In fact, in the past 40 years, only a handful of economies, nine of 167 in the sample in 2010 - Cyprus, Czech Republic, Greece, Ireland, Korea, Malta, Portugal, Slovenia, and Taiwan Province of China-have crossed the $75^{\text {th }}$ percentile of the relative income distribution. Seven of them are European countries, which were already upper-middle income countries and above Malaysia's income in 1970, and later became part of the European Union. It is not surprising that these countries grew relatively fast. The remaining two economies, Korea (KOR) and Taiwan Province of China (TPC), made it to

\footnotetext{
${ }^{4}$ See http://data.worldbank.org/about/country-and-lending-groups.

${ }^{5}$ The 1970 is used as a benchmark year as both the country coverage and the data quality tend to decline in earlier decades.

${ }^{6}$ Bulman, Eden, and Nguyen (2012) define the middle-income range at 10-50 percent of the US GDP per capita.

${ }^{7}$ In 1970 , these thresholds were $\$ 3250$ and $\$ 9300$, respectively.
} 
high-income status while starting at a level of development below that of Malaysia (MYS) in 1970 (Figure 1). ${ }^{8}$

Figure 1. GDP per capita relative to the US (2005 PPP \$), 1970 vs. 2010

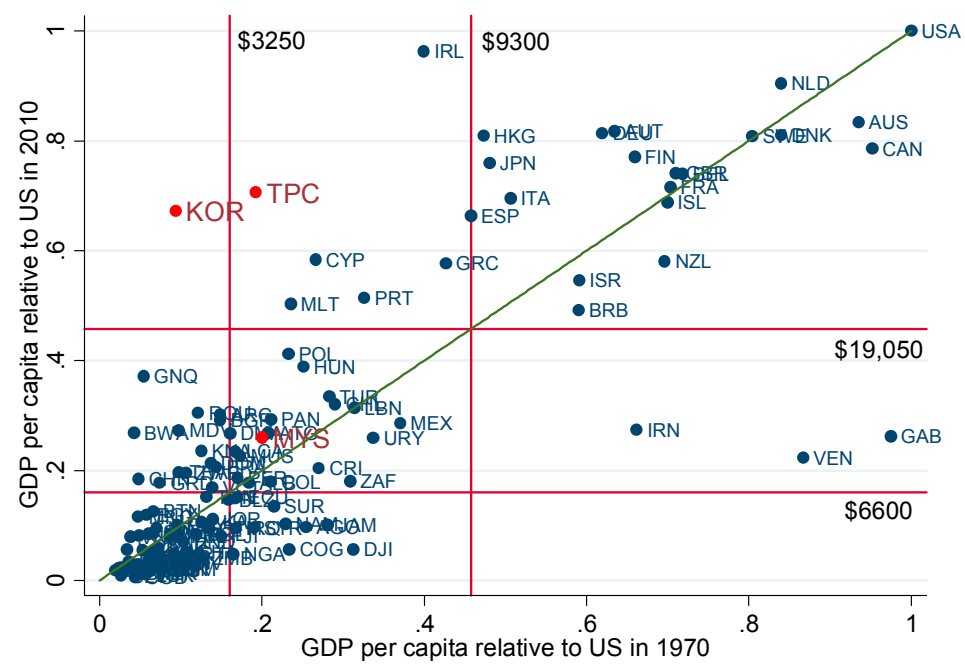

The growth stories of Korea and Taiwan Province of China illustrate the leap of the Asian tigers. On average over the past 40 years, Korea and Taiwan Province of China grew by about 7.1 percent and 5.3 percent per year, respectively. In contrast, Malaysia grew by 2.8 percent annually (Figure 2). Taiwan Province of China overtook Malaysia around 1975, while Korea caught up in 1985. Only 5 years later, in 1990, Korea reached the level of income it took Malaysia to reach in 30 years. Although Malaysia grew from about $\$ 4100$ to about $\$ 10,800$ over $1970-2010$, it barely changed its relative position. It reached 26 percent of the US income per capita in 2010 from 20 percent in 1970. Korea and Taiwan Province of China skyrocketed from less than 20 percent of the US income in 1970 to above 65 percent in 2010 .

Chile and Thailand, countries that are comparable to Malaysia in terms of development or geography, have grown relatively similar to Malaysia (Figure 3). Chile started at a higher level, about 30 percent of the US income per capita, but was about 32 percent in 2010, growing at an average 2.1 percent per year in 1970-2010, less than Malaysia. Thailand, starting at about 10 percent of the US income per capita, grew at about 4.4 percent per year, reaching 20 percent in 2010. While Chile's GDP per capita has been relatively close to Malaysia's over time, it increased substantially in the 2000s as copper prices went up. Thailand's GDP per capita did not catch up with Malaysia's income per capita.

\footnotetext{
${ }^{8}$ There are 143 countries in the sample in 1970. We do not have the data for a few European countries in 1970 (e.g. former Yugoslavia and Baltic states) but we counted those that are above the high-income threshold in 2010. Slovakia was just under $\$ 19,000$ in 2010 , a bit below the high-income threshold.
} 


\section{Figure 2. Malaysia, Korea, and Taiwan Province of China: GDP per capita (2005 PPP \$), 1970-2010}

(Vertical lines represent catch-up years: Taiwan Province of China in 1975 and Korea in 1985)

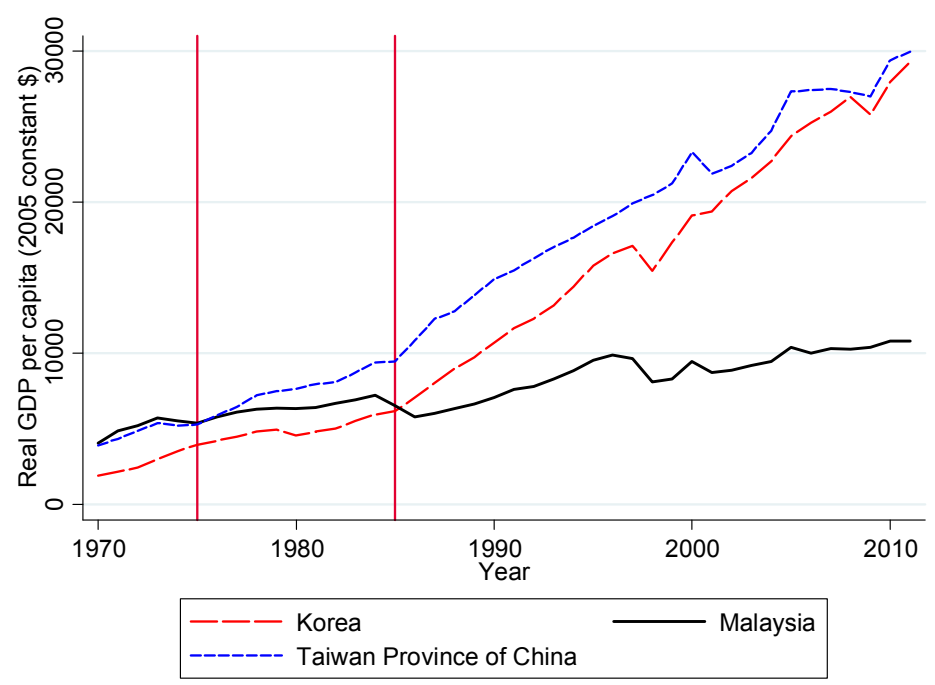

Figure 3. Malaysia, Chile, and Thailand: GDP per capita (2005 PPP \$), 1970-2010

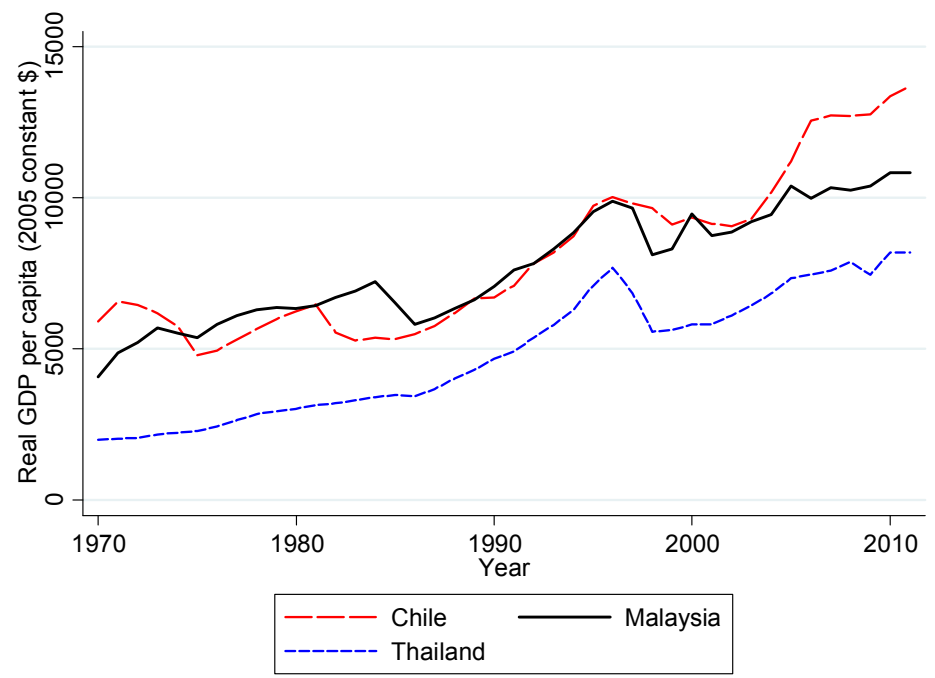

The potential causes of the middle-income trap are evident in productivity patterns. Total factor productivity (TFP) grew by about 1.8 percent per year on average in 1970-2010 in Korea and Taiwan Province of China, while it increased by 0.8 percent in Malaysia (Figure 4). As Taiwan Province of China and Korea overtook Malaysia in GDP per capita terms in the mid-70s and mid-80s, respectively, their productivity levels rose substantially. Malaysia witnessed stagnant and declining productivity levels in the mid-70s to mid-80s. ${ }^{9}$ Policies that

\footnotetext{
${ }^{9}$ Our TFP calculations are based on Caselli (2005) using Penn World Tables 8.0 and show a similar pattern to the TFP calculations in Penn World Tables 8.0. The estimates done by Malaysia Productivity Corporation indicate rising TFP in the same period, but at a slower pace than TFP of Korea and Taiwan Province of China.
} 
Korea and Taiwan Province of China pursued then set the stage for a rapid take-off of productivity and growth. The rise of China in the 1990s could have been a contributing factor with low-productivity activities outsourced there. In contrast, Chile witnessed stagnating TFP. Thailand's TFP grew by 1.2 percent but Thailand started at a lower level of development (Figure 5). The manufacturing output per worker in Malaysia has also lagged behind that of Korea and Taiwan Province of China (Figure 6).

Figure 4. Malaysia, Korea, and Taiwan Province of China: TFP $(1970=100), 1970-2010$ (Vertical lines represent catch-up years: Taiwan Province of China in 1975 and Korea in 1985)

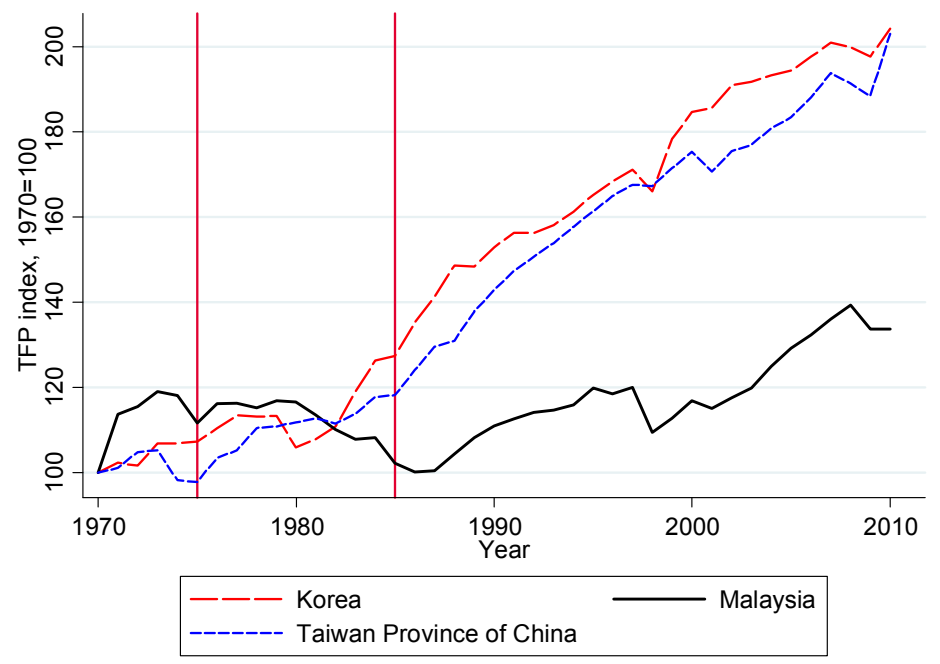

Figure 5. Malaysia, Chile, and Thailand: TFP $(1970=100), 1970-2010$

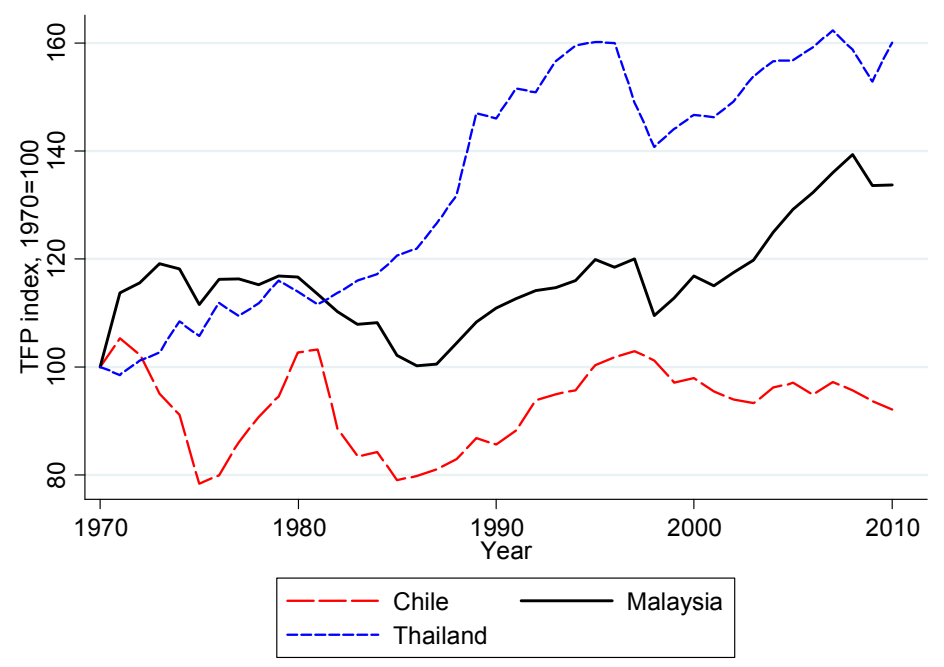

\section{The Missing Link: Creating OWn TeChnOlogy}

A theoretical explanation for the middle-income trap relates to productivity slowdowns as gains from low-cost labor and foreign technology imitation diminish in moving through the stages of development. As a low-income country becomes a middle-income country, it needs to find new sources of growth as benefits of low-cost labor and productivity gains from 
sectoral reallocation from agriculture to manufacturing and easy foreign technology adoption fade away. Wages rise and competitiveness is eroded. Moving away from labor-intensive manufacturing to sustain increases in productivity and per capita income requires innovation - the use of new ideas, methods, processes, and technologies in productionrather than imitation (Aghion and Howitt 1992).

Figure 6. Manufacturing output per worker, 1975-2005

(Vertical lines represent catch-up years: Taiwan Province of China in 1975 and Korea in 1985)

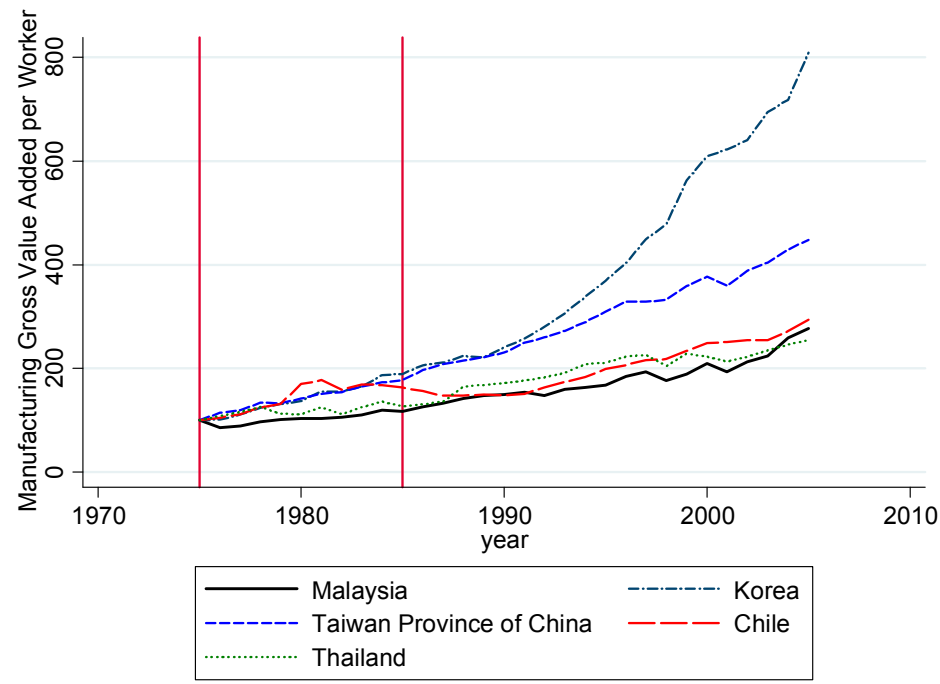

Innovation-driven growth is key to avoiding the middle-income trap. The recent China 2030 report emphasizes innovation rather than the reliance on foreign technology (World Bank and the Development Research Center of the State Council, P. R. China 2013). Acemoglu, Aghion, and Zilibotti (2006) argue that if countries do not switch from an investment-based strategy to an innovation-based strategy before a certain level of development, they may get stuck in a "non-convergence trap" without reaching the world technology frontier. Similar to Gerschenkron (1962), the authors suggest that government intervention to increase investment and faster adoption of existing technologies are desirable at the early stages of development. However, to move to an innovation-based strategy, competition policies and checks and balances on political interests are needed to ensure convergence to the frontier.

The middle-income trap could also be characterized by a misallocation of talent and a limited access to advanced infrastructure. Agenor and Canuto (2012) show how a low-growth trap could occur in a model of an endogenous occupational choice, access to basic public infrastructure (e.g. roads, electricity, and basic telecommunications) and advanced public infrastructure (e.g. broadband and other advanced information and communication technologies), and knowledge network externalities. The low growth-trap results in a low share of high-skill individuals investing in the advanced skills needed for a design or innovation sector. To implement an innovation-based strategy, the authors argue that an investment in advanced infrastructure would increase productivity and hence wages in the design sector, inducing labor to invest in needed skills and move to a more productive design sector. With learning-by-doing and knowledge network effects, productivity gains are increasing, moving the economy to a high-growth equilibrium. 
To create sustainable growth, a country needs to constantly produce new goods and adopt and develop new technologies. In his seminal paper "Making a Miracle," Lucas (1993) argues that constantly introducing new goods rather than only learning on a fixed set of goods is what is needed to generate productivity gains for a sustained growth miracle. Learning-by-doing or learning-on-the-job is one of the most important channels of accumulating knowledge and human capital in this process. Producing the same set of goods would rapidly lead to stagnation in productivity. In contrast, introducing new goods and tasks would allow managers and workers to continually learn and move up the "quality ladder" (see the seminal paper on creative destruction by Aghion and Howitt 1992). To do this on a large scale, Lucas argues, the country must be a large exporter.

Empirically, education and export sophistication are important determinants of growth. Hausmann, Hwang, and Rodrik (2007) and Cherif and Hasanov (forthcoming) show empirically that export sophistication is one of the major determinants of growth, accounting for initial conditions, institutions, financial development, trade openness, and other growth factors. Eichengreen, Park, and Shin (2013) show that countries with a high share of population with secondary and tertiary education as well as a large share of high-technology exports are less likely to experience growth slowdowns. The authors emphasize the importance of moving up the "quality ladder" to avoid the middle-income trap. Bulman, Eden, and Nguyen (2012) suggest that escapees from the middle-income trap experienced rapid structural transformation from agriculture to industry, higher human capital and innovation, greater export orientation, macroeconomic stability with inflation less than 10 percent, and small increases in inequality.

By and large, Malaysia fares relatively well in major growth determinants such as export sophistication and schooling in comparison to Korea of 1990 (when Korea reached the level of GDP per capita that Malaysia had in 2010). The export sophistication level of Malaysia grew substantially in the 1990s but stagnated in the 2000s (Figure 7). Nonetheless, Malaysia's level in 2006 was about the level of Korea in 1990. Interestingly, Thailand's export sophistication has grown substantially while Chile's has stagnated. Similarly, Malaysia's years of schooling in 2005 were about the same as that of Korea in 1990 (Figure 8). Despite higher years of schooling, Chile did not witness productivity and export sophistication growth that Thailand and Malaysia did. Malaysia caught up with Chile around 2000 , and years of schooling grew at a similar rate afterward.

Malaysia seems to have the standard ingredients of a sustainable growth recipe. In particular, it compares favorably to Korea and Taiwan Province of China in the 1970s and mid-1980s when these economies overtook Malaysia. Export sophistication levels and years of schooling are relatively high as seen above. Other standard growth determinants such as infrastructure, macro-stability, institutions, trade openness, foreign direct investment (FDI), etc. do not appear to be the binding constraints for an increase in productivity especially in comparison to Korea and Taiwan Province of China in the 1980s. Since the liberalization of the mid-80s and FDI-led export promotion strategies, Malaysia has managed to attract many multinational corporations (MNCs), diversify its exports, and later on even somewhat upgrade its export basket by providing different incentives to MNCs to do so. If Malaysia compared relatively well to Korea and Taiwan Province of China when these economies 
were at similar levels of development, then what is the binding constraint for Malaysia to increase its productivity growth? It is a crucial question as policy should focus on the major elements in which Korea and Taiwan Province of China did differ from Malaysia at the time.

Figure 7. Goods Export Sophistication (Constant 2000 PPP \$), 1976-2006

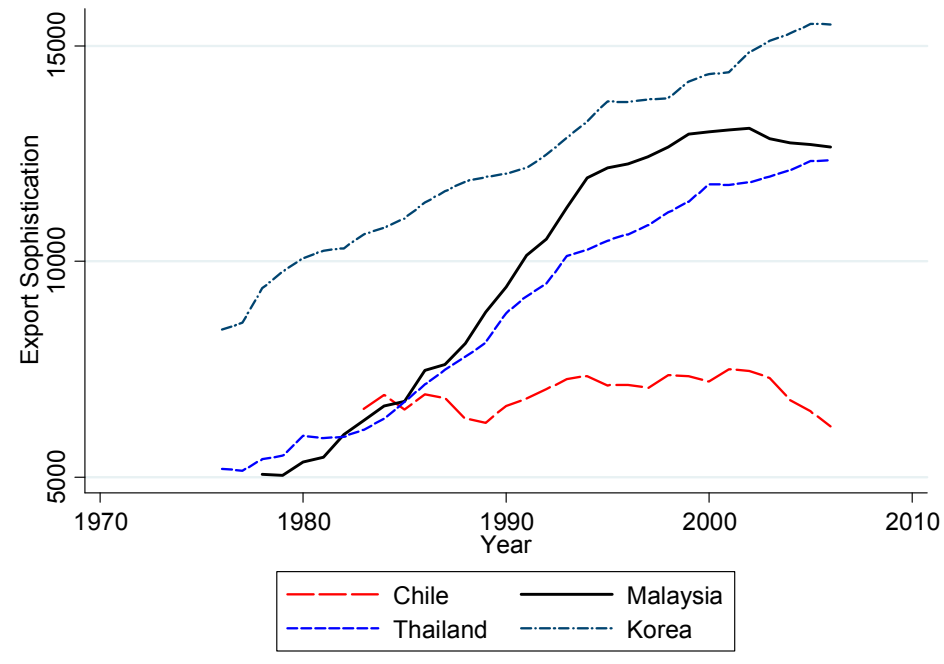

Figure 8. Average Years of Schooling

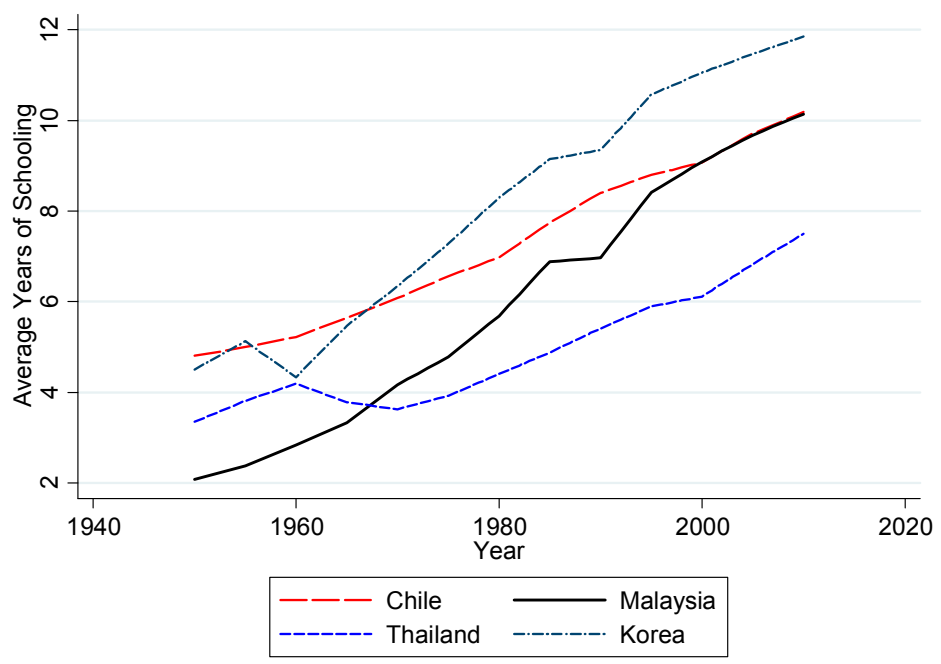

We argue that the missing link in Malaysia's growth strategy in comparison to Taiwan Province of China and Korea is local technology creation. Technology creation was relatively low as is evident by the number of patents granted in the United States. For instance, when Korea overtook Malaysia in 1985, it was receiving about 50 patents per year while Malaysia was being granted less than five (Figure 9). The number of Malaysia's patents granted in 2013 (about 220) is still below Korea's when it had a comparable level of income in 1990 (about 300). The gap between the two countries in 2013 widened to about 50 times. Lower R\&D spending in Malaysia contributed to a smaller number of granted patents (Figure 10). R\&D expense was much lower in 2011, a little over 1 percent of GDP, than it 
was in Korea of the 1990s (more than 2 percent of GDP) and even of the mid-80s, 1.3 percent in 1984 (Tran 2013). Moreover, the share of graduates in engineering, manufacturing, and construction was larger (about 35 percent of tertiary graduates) in Korea in the 1990s than that in Malaysia in the late 2000s (about 25 percent). The figures were reverse for social science graduates, 21 vs. 33 percent (Tran 2013).

Figure 9. US Patents Granted, 1977-2013

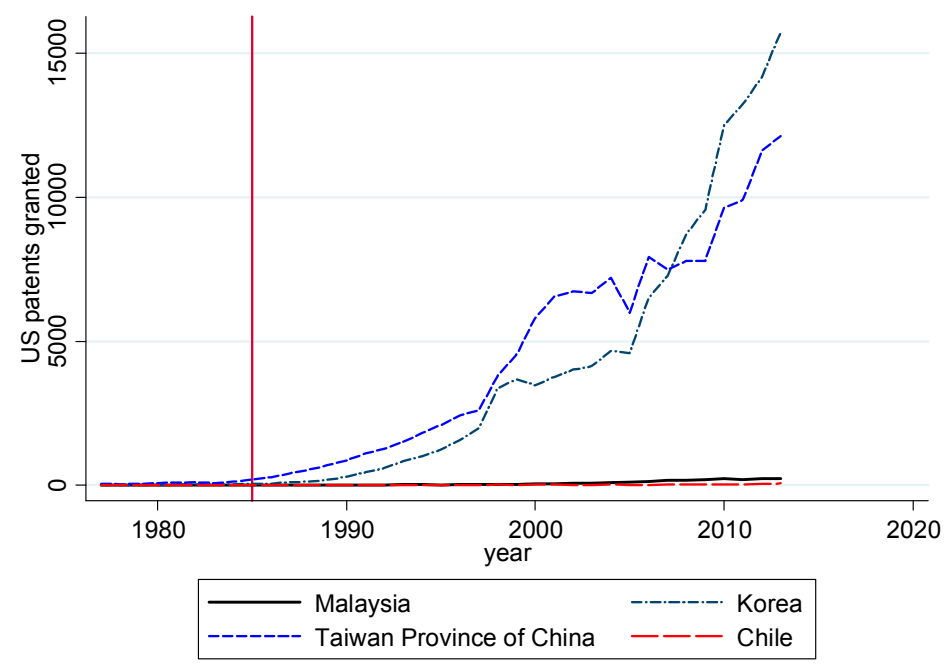

Figure 10. R\&D Spending, 1996 vs. 2011

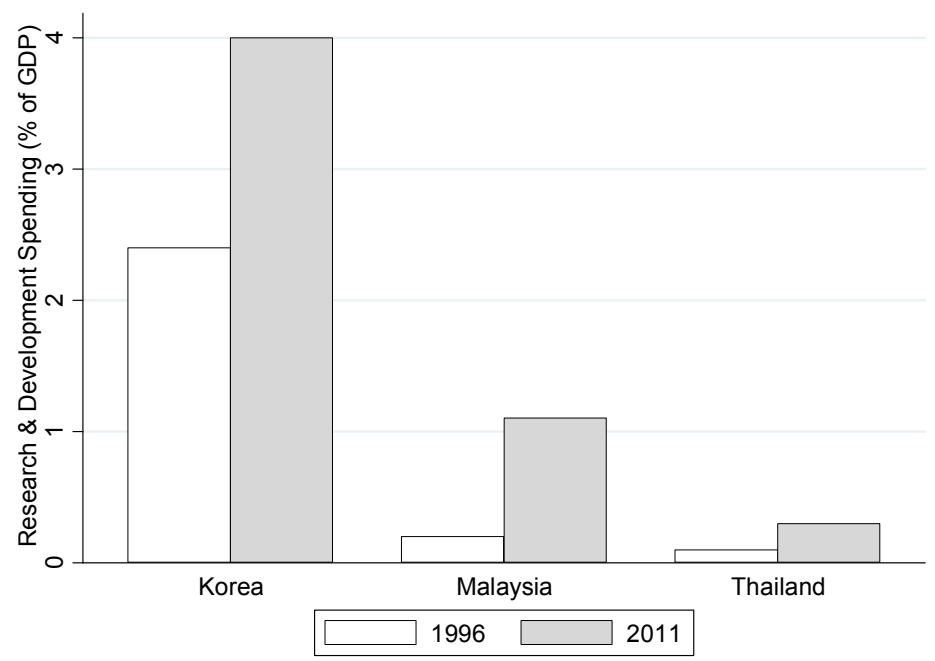

Malaysia tried hard to facilitate technology transfer and diffusion from MNCs, especially in the electronics sector, beginning as early as the late 1980s, but the strategy did not pay off to a large extent (Jomo 2001). Although MNCs contributed to export sophistication and upgrading (Figure 7) after being offered many incentives, the country did not see much technology creation (Figures 9-10) nor high productivity growth (Figures 4-6). Only a few local firms in the electronics sector, which has the largest manufacturing exports, managed to grow (Best 2007). Ever since the 1970s, export manufacturing has been driven by MNCs, as 
in Thailand but to a lesser extent. However, in contrast to import-substitution (IS) industries, the export-oriented industries, except natural resource industries, had poor linkages with the rest of the economy (Jomo 2001, Rasiah 2001).

At an early stage, Malaysian authorities understood the importance of technology creation and mostly focused its efforts on various incentives to MNCs to diffuse technology. The Industrial Master Plan (1986-95) attempted to develop technological upgrading in local companies and changed FDI policy to support this initiative. Yet a region-wide recession in mid-80s crippled the implementation of the plan, and the heavy industry program was retrenched. Large-scale privatization followed. The recovery was placed on attracting FDI with liberalization policies and generous incentives to increase FDI and bring even suppliers of MNCs. Investment flowed in. In the 1990s, technology parks were created for technological upgrading, and MNCs were further encouraged to climb the "quality ladder." Government research institutes were set up, and training and skill development of locals were much improved. With the Vendor Development Program, the state became more forceful in providing quality local suppliers to $\mathrm{MNCs}$, and some suppliers started getting large order volumes while R\&D in MNCs increased. The cumulative efforts succeeded to some extent (Felker 2001).

However, the technology diffusion from MNCs to local industries was limited. Interestingly, the majority of local firms, even in high-tech sectors, did not meet many requirements needed to get incentives, hampering the local firm development (Felker 2001). Even the region of Penang that was quite successful in attracting MNCs in the electronics sector, which experienced strong growth in output and exports, lacked high value-added production. Although MNCs did provide some support to develop local suppliers and conduct personnel training, only a few local firms, started by former MNCs' employees, in Penang's electronics cluster managed to grow and export. Overall, the Malaysian clusters lacked the "packaging and integrating" capabilities of Singapore and product development and technology management capabilities of Taiwan Province of China (Best 2007). The empirical evidence confirms higher technological intensities in foreign electronics firms than local firms in Malaysia, unlike Taiwan Province of China (Rasiah 2004). In addition, using a sample of auto parts firms, Rasiah (2007) shows that foreign ownership helps increase exports, but R\&D intensities are mostly driven by local firms.

It is not completely surprising that MNCs did not serve as a conduit for technology diffusion to local firms. MNCs preferred their own suppliers, used in-house production or imports of inputs, sourced only simple content to local firms, and repatriated profits. Local value added increased but not the technology diffusion (Felker 2001). There are other explanations contending that MNCs would not drive technology creation and diffusion locally. Strong intellectual property environment and relevant conditions for R\&D may be lacking as there could be a lack of skilled workers and other relevant support. MNCs may have less incentive to train or may provide suboptimal level of training to local staff as high-skilled scientists and engineers become mobile once trained. In addition, the R\&D department in companies tends to be located in proximity to the marketing department, usually housed at headquarters, and less R\&D happens at foreign locations. Lastly, as argued by Lucas (1993), for sustained productivity gains, introduction of new goods and processes is essential. MNCs, by the 
nature of their business, would not introduce a sufficient number of new products at foreign locations. Learning-by-doing in MNCs would have limited productivity gains.

Thailand, which had large local business interest, also attempted to attract FDI by liberalizing and providing incentives and used local content programs to create local suppliers. By the mid-90s, Thailand had more local firms than foreign-owned ones, but mostly in low-tomedium technology market (Felker 2001). Both Malaysia and Thailand relied on MNCs for technological upgrading rather than own technology creation.

Singapore was more forceful in creating local firms and technology despite the large inflow of FDI and the presence of MNCs. Initially, Singaporean SOEs engaged with MNCs as subcontractors, but the Ministry of Finance was keen on creating local non-state-owned MNCs (Low 2001). The cluster-based industrialization in the 1990s led by Singapore's Economic Development Board involved many stakeholders, including MNCs. For instance, the electronics cluster was spearheaded by the Singapore Technologies Group, an SOE, working in tandem with government research institutes, universities, and MNCs (Low 2001). Unlike the Malaysian electronics clusters that had relatively low value added, the Singaporean electronics cluster moved up the value-added ladder as low-cost manufacturing was no longer viable (Best 2007).

The empirical literature on FDI and technology transfers generally finds mixed results of the effect of the presence of MNCs on technology diffusion. The heterogeneity of MNCs and domestic firms across countries affects the robustness of estimated spillover effects. In a survey article, Javorcik (2010) argues that MNCs provide knowledge transfer not only to their foreign affiliates, but also to their local suppliers. In addition, MNCs generate spillovers to other local firms through demonstration effects, increased competition, worker mobility, and information sharing about export markets. In another survey article, Hayakawa, Kimura, and Machikita (2010), indicate that negative and positive spillover effects of MNCs on domestic firms' productivity could cancel out, depending on the actions taken by these firms. MNCs' lack of interest in providing knowledge and training, low absorption capacities of domestic firms (including R\&D intensity), negative effects of competition, and weak supplier relationships between domestic firms and MNCs could contribute to the relatively small or nonexistent spillover effects. Smeets (2008), in a comprehensive review of the literature, further confirms mixed results of productivity spillovers.

Even if MNCs generate positive spillovers to local firms, the key to domestic innovation and sustained productivity growth is exporting activities of domestic firms. Sun and Hong (2011), in a large sample of Chinese firms, conclude that exporting firms are more likely to innovate while ownership does not have a direct or indirect effect on a new product development of the firm. Further, using regional Chinese data, Jarreau and Poncent (2012) show that export activities of domestic firms and domestic export sophistication have the largest effect on subsequent growth, while foreign firms mostly contribute to high total export sophistication measure observed in the Chinese data. The authors argue for policies to support domestic innovation rather than promotion of FDI. Interestingly, most high-tech sectors have a low share of domestic value added in Chinese exports, as these industries tend to have a high share of processing exports dominated by foreign enterprises (Ma, Wang, and Zhu 2013). 
The experience of Korea and Taiwan Province of China shows that developing domestic technology and firms at the technology frontier is key to escaping the middle-income trap. Relying on MNCs, even if positive spillovers exist, to get local firms develop their own technology is not sufficient to achieve high and sustained productivity gains. Although Malaysia tried to upgrade its local technology, it did not succeed to the extent of Taiwan Province of China and Korea. The section below provides case studies of Taiwan Province of China's electronics sector and Korea's automotive sector to draw some of the key elements that are needed to succeed to create local technology and sustained productivity growth.

\section{Creating OWn Technology: In the Footsteps of Taiwan Province of China AND KOREA}

\section{Taiwan Province of China's "Spin-offs" and the Government as a Venture Capitalist}

The electronics sector has been the main engine of Taiwan Province of China's spectacular growth for the past decades. The sector started developing in the early 1970s when Taiwan Province of China was moving away from its import-substitution strategy. When the government picked high-tech electronics as a strategic sector, it was facing a particularly unfavorable environment. Domestic private firms were unwilling to risk entering into new technologies; the international market was dominated by large integrated manufacturers from advanced countries; and a tight budget made it difficult to finance "champions" as Korea did with "chaebols."

To overcome these obstacles, the government designed an original strategy with the following features: (i) the initial focus was on creating small and medium enterprises (SMEs) in close and long term industrial relationship with MNCs instead of global brands; ${ }^{10}$ (ii) the government did not rely on MNCs to transfer and diffuse new technologies; rather, it relied on public and quasi-public research institutes to spin off firms introducing new technologies; (iii) technological leapfrogging to the frontier took place at an early stage of development, and it was decided and led by the government; and (iv) the massive investment in training engineers abroad led to the formation of a "technical community" with valuable technical experience and informal connections with the Silicon Valley.

The institutional apparatus put in place in the 1970s played an essential role in Taiwan Province of China's technological upgrading. It started in 1973 with the creation of the Industrial Technology Research Institute (ITRI), an umbrella organization to actively promote the introduction of new technologies in electronics. Its main body was the Electronics Research Services Organization (ERSO) created in 1974 to lead the R\&D effort. The Science and Technology Advisory Group (STAG) was founded in 1978 under the auspices of the premier's office. Its purpose was to advise the government in its technological development strategy. Early on, STAG encouraged electronics clustering in a technology park, which led to the creation of the Hsinchu technology park in 1980 (Fuller 2002 and Green 2008).

\footnotetext{
${ }^{10}$ Fuller (2002) describes it as "leveraging" MNCs.
} 
The typical mode of ITRI's operation was to negotiate a license or technology-sharing agreement with a US electronics firm. ITRI and ERSO would subsequently send their staff for training in the production facilities of their US partner. The returning staff would set up an experimental production unit within ERSO facilities. Finally, the team of engineers and technicians involved in the new technology would form a "spin-off" firm with about 40-50 percent of its initial capital coming from the government. ERSO would continue to assist the newly formed firm with training and would even allow the firm to produce from its own facilities.

United Microelectronics Company (UMC) was one of the first spin-off firms based on a technology-sharing agreement with RCA, the US electronics firm, initiated in the mid-1970s. Within the next few years 259 ERSO personnel were sent for training to RCA's US facilities. In parallel, an experimental production unit was set up within ERSO facilities, and in 1980 UMC was founded. Its first CEO was the deputy director of ERSO, while 14 of its first employees were ERSO staff working on the semiconductor technology (Chen et. al. 2001). About one-half of the initial funding came from the government through the high-tech promotion fund of its state-owned bank Chiaotung. Despite all the preparatory work in terms of technology acquisition (the technology was practically provided for free by ITRI) and the huge potential export markets, private investors were reluctant to participate. In fact, the government had to use implicit pressure to "convince" several private firms to contribute small amounts to the initial capital (Fuller 2002). In 2013, UMC was the third company in the world in the semiconductor foundry sector with about 10 percent market share. ${ }^{11}$ In fact, the world's biggest producer in 2013 was the Taiwan Province of China Semiconductor Manufacturing Company (TSMC) with a market share of about 50 percent. TSMC is another successful spin-off firm created by ITRI and ERSO.

Back in the 1980s, the experience of UMC led STAG to decide it was time to leapfrog to the technological frontier in semiconductors (Hong 1997). Despite strong opposition from different parts of the government, including from some ERSO officials, the Very Large Scale Integration (VLSI) project went ahead pushed by top level officials (Fuller 2002). Starting in 1983, ERSO led the R\&D effort in design and production, and in 1987, TSMC was spun off out of ERSO in partnership with Phillips. TSMC did not only innovate technologically but it also initiated the "the pure-play foundry model," which it still dominates. ${ }^{12}$ By the late 1980s, within a decade of the first spin-off operations, Taiwan Province of China essentially caught up with the world technology frontier in terms of integrated circuit resolution (Mathews 2006, p. 99).

The spin-off system of ITRI and ERSO successfully created 18 firms in different sub sectors of the semiconductor industry in the 1980s, including design (Lee and Pecht 1997 and Smart and Smart 2005). In turn, the firms either diffused technology directly through a second

\footnotetext{
${ }^{11}$ See the IC insight report at http://www.icinsights.com/news/bulletins/Top-13-Foundries-Account-For-91-OfTotal-Foundry-Sales-In-2013/.

${ }^{12}$ Firms in this business model do not offer integrated circuit products of their own design. Instead, they only produce for an industrial partner, which usually does not have production capacity.
} 
round of spin-offs or indirectly when the employees left to set up their own companies. The industry also diversified horizontally (e.g. into DRAM and flat screens) again under the direction of ITRI and STAG. The government, however, decided to end the spin-off system in the mid-1990s. By then, the leading firms in the electronics sector were already investing heavily in R\&D, and Taiwan Province of China was at the technological frontier.

Returning skilled workers from the US played an important role in driving Taiwan Province of China's technology creation. Interestingly, their numbers became significant only in the 1990s after ITRI and ERSO jumpstarted the sector and created enough dynamism to make it attractive for the skilled workers to return. To provide for skills needed in the sector, the early investment in training engineers and scholarships to study abroad were massive. Thousands of engineers were sent abroad every year in the 1970s and 1980s, including "entire graduating classes from Taiwan Province of China's most elite engineering universities." (Saxenian and Hsu 2001). The authorities did not decrease their investment in scholarships abroad despite the low rate of returnees (less than 10 percent) among graduates from the US in the 1970s-early 1980s. ${ }^{13}$ By the mid-1980s, a large number of engineers from Taiwan Province of China were working and living in the Silicon Valley. They accumulated technical experience in the industry and acquired informal relationships in the Valley. It is no surprise that among the first prominent members of ITRI and ERSO as well as the firms spun off, many were returnees who used to hold senior positions in large US electronics firms. Moreover, the geographic proximity and the critical mass attained by the expatriate engineers led them to form a "technical community" based on both informal and formal ties with the Silicon Valley. ${ }^{14}$ Up to the present day, this technical community has played a crucial role as a bridge between the Silicon Valley and the Hsinchu technology park.

The use of venture capital (VC) to finance firms was also brought to Hsinchu by the technical community of expatriates in the Silicon Valley. It is common in the literature to explain the dynamism of Taiwan Province of China's electronics sector by the widespread use of VC financing. However, VC financing became significant only in the early 1990s as the number of returnees had increased (Saxenian 2001). Until then, most of the first indigenous firms entering new technologies were spin-offs. The ITRI's spin-off model described above could be considered as the state acting like a venture capitalist. Indeed, the spin-off projects were aimed at introducing new technologies, were highly risky, and generally involved modest amounts in terms of the initial capital invested. About one-half of the initial \$14 million for UMC and one-half of the \$206 million for TSMC came from the government. As a comparison, the VLSI project, which led to the spin-off of TSMC, had a budget of $\$ 72$ million over the 1983-88 period. In addition to providing financing, ITRI and ERSO actively engaged in acquiring the technology and helping firms with experimental production facilities and training.

\footnotetext{
${ }^{13}$ See Saxenian and Hsu (2001).

${ }^{14}$ See Saxenian and Hsu (2001) for more details about how the state actively helped institutionalize the technical community.
} 


\section{Korea's Chaebols and the Visible Hand of the State}

To spearhead the development of sectors with high productivity gains, linkages, and spillovers, the Malaysian government ventured into the automotive sector and established a national car company Proton in 1985. It also had an ambitious plan to create a network of local suppliers for the car company.

The venture has been successful in several dimensions but overall, has not achieved the "global brand" status and did not help develop an innovative automotive cluster. It succeeded in creating valuable managerial and engineering skills. A network of few successful autoparts exporters has developed, and Proton's annual production capacity has reached about 500,000 cars. However, the firm has not managed to export substantial quantities and is now challenged by foreign automakers in the domestic market despite tariffs and subsidies.

In contrast to Proton, Korea's Hyundai has succeeded in creating a "global brand," and we contend that a push to export and a bet on several chaebols to simultaneously develop cars were key elements in Korea's success. As Korea and Malaysia were at the same level of development in 1985, Korean automakers probably faced quite similar challenges such as vested interests, technology acquisition, and lack of required human capital. Further, it was not a smooth ride for the Korean auto industry as several of Korea's firms declared bankruptcy and/or were restructured in the 1990s (e.g. KIA). Nonetheless, on a global arena, one large auto firm Hyundai emerged as a success.

The push to export represents a major difference between Proton and its Korean counterparts' strategies. While Proton eventually focused on the domestic market and has not strongly engaged in developing export markets, except for a short period, Korean automakers vigorously pursued a "move first, then learn and adjust" approach to exporting. Proton's cumulative exports represent about 12 percent of its total production since its creation in the mid-1980s (400,000 out of 3.5 million cars). At the peak, annual exports reached about 30,000 cars mostly to the UK in the late 1990 s, but shrank to an insignificant number by 2013. It was in those days when Proton acquired the UK's Lotus and started seriously focusing on exports, but afterwards the momentum seemed to have stalled. In contrast, Korean car manufacturers, in particular Hyundai, have had a much more aggressive approach since the beginning. In the mid-1980s when the Korean total sales were about 250,000 per year, Hyundai Motors decided to build a 300,000 annual production capacity plant mainly targeting the US, the biggest and most competitive market (Steers 1999). ${ }^{15}$ At that stage Hyundai had barely started designing its own car and its quality was lagging behind other car manufacturers. Hyundai management expected their first attempts at exporting to be failures but also planned to learn from these failures and adjust accordingly.

The drive to export could be attributed to a large extent to state policies (Woo 1991). In exchange for state support, in particular loans with low and often negative real interest rates,

\footnotetext{
${ }^{15}$ Moreover, Hyundai decided from the early stages to build its own dealership network in the US and invested in advertisement. In retrospect, this move shows how bold its strategy was at the time when most other car manufacturers like Proton stroke deals with existing large firms to use their dealership networks.
} 
chaebols had to quickly gain market shares abroad. Loans were often conditional on explicit and quantified exports targets, while there are many accounts of political pressures from the highest levels of the government. Not reaching exports targets often implied senior management dismissal, and accountability was strongly enforced. The pressure to export forced Hyundai to move even faster in terms of R\&D effort and technological upgrading. By 1991, it already produced its first engine according to its own design and its first electric car.

State policies also bet on several chaebols to develop the auto industry with only a few of them eventually succeeding. Compared to Malaysia's Proton and later Perodua, several chaebols entered the industry with, ultimately, only a few successful firms emerging. Indeed, to name a few, Daewoo, Hyundai, KIA, Asia Motors, and Samsung all attempted at building cars at some point, while most of them also invested in electronics, chemicals, and shipbuilding. Chaebols were encouraged to enter the automotive industry despite little or no experience in the field. For example, prior to setting up its automotive subsidiary in the 1970s, Hyundai's activity was mainly in construction. Korea followed Japan that pursued a similar strategy decades earlier (Chang 2013). By the early 2000s, the industry witnessed major restructuring and mergers (e.g. Asia Motors was closed in 1999 and Hyundai took over KIA in 1998) such that the industry became largely dominated by Hyundai-KIA. Although the industry received subsidies and benefitted from high tariffs to protect the domestic market at the early stages, automakers had to face intense competition domestically and were pressured to export and face even stiffer competition abroad.

\section{Toward a High Productivity and High Linkages Economy}

High productivity and high value-added sectors that generate extensive linkages with the rest of the economy are crucial to sustainable growth. Building domestic capabilities and creating own technology in these sectors are key elements to achieving sustainable growth. In many instances, it would imply to enter sectors with little or no comparative advantage, lack of skills, experience, and resources, and high risk of losing money. However, in the long run, these sectors offer high returns and are the ones that could catapult the country into high income status. This high risk-high return tradeoff is exemplified by Nokia's mobile unit (part of a Finnish logging company at the time) that had incurred losses for about 20 years and Toyota that had not been profitable for 30 years (Chang and Lin 2009). As Chang put it, the question is not whether comparative advantage should be defied or not, but how far from comparative advantage the state should push (Chang and Lin 2009).

Malaysia did attempt at moving up the "quality ladder" and creating linkages around the existing exporting industries. The country entered into downstream and upstream activities such as medical materials based on rubber and research in biotechnology engineering to improve palm production (Jomo 1997). The tire industry, however, did not manage to take off (Jomo 1997), showing the importance of competing in international markets and enforcing accountability. Petronas, the state oil company, pursued international diversification of its assets. Oil extraction and refining industries offer further opportunities as they require a large number of manufacturing inputs (machinery, metals, pipes, platforms) as well as high value-added services (software, geological surveys, engineering studies) with high employment potential. 
Norway's state policies to develop an oil and gas suppliers' cluster in the 1970s represent an interesting case study. First, the government intervened directly in the procurement of oil operators. The Norwegian Petroleum Code imposed that operators communicate their lists of bidders to the government, which in turn had the authority to impose the inclusion of Norwegian firms in the list and even to change who was awarded the bid (Leskinen et al. 2012). Second, the licensing process required foreign operators to come up with plans to develop the competencies of local suppliers (Heum 2008). Third, starting in the late 1970s, the government imposed a minimum of 50 percent of R\&D needed to develop an oil field to take place in Norwegian entities (Leskinen et al. 2012). Although the restrictions were lifted in 1994 when Norway signed trade agreements with the EU, the government continued to support the suppliers though the INTSOK foundation to encourage them to internationalize their activity. Eventually, the suppliers' cluster became successful, including in international markets, spanning a large array of high value-added industries such as subsea, geology, and seismic, helped develop required skills, and employed directly about 114,000 workers in 2009 , or more than five times the employment of the operators in the oil and gas sector (Sasson and Blomgren 2011a, 2011b).

To create or grow "system integrators," or large firms to spearhead the sector development (e.g. Proton), and develop high-tech clusters (e.g. electronics) and "global brands" (e.g. Petronas) in the tradable sector, the state needs to tackle prevailing market failures, leading to high-risk and high-return endeavors, and provide the necessary support for firms to follow." 16 The bigger the technological leap is (or the farther away from comparative advantage the country is), the bigger the risk is and the longer it could take to discover the true outcome of initial investment (Rodrik 2005 and Chang and Lin 2009).

High productivity and high value-added tradable manufacturing and high-tech innovation sectors, including high-skill services, are key sectors to enter. High-tech sectors, or innovation sectors, have large spillover effects on job creation (Moretti 2013). The growth of global value chains (GVCs) could further support entry of local firms to produce specific goods in the supply chain of the country's MNCs or Asia at large. Nevertheless, the major focus of policy should be on own technology creation undertaken in high-productivity manufacturing (e.g., automotive) as well as innovation sectors.

\section{The Perils of Relying on Comparative Advantage: The Case of Chile}

In the 1970s, Chile followed very liberal policies rather than pursuing the import-substitution strategy that many other countries did. Chile backtracked after the 1982 crisis when it raised again its tariff on imports. Overall, the country followed a relatively neutral policy toward export diversification and relied less on direct state intervention. Instead, it used indirect tools to spur export growth with a special emphasis on SMEs. An important exception is the "reintegro simplificado" (simplified reintegration) program which spanned the period of

\footnotetext{
${ }^{16}$ The public sector is not necessarily unfit for the task as the example of Singapore shows where the government-linked companies played a significant role in the economy since independence and are run efficiently on a competitive and commercial basis (Ramirez and Tan 2004).
} 
1985-2003. It consisted of an export subsidy to help firms export in non-traditional sectors (Varas 2013).

In the 1990s and early 2000s, Chile's state intervention focused on helping SMEs through the Chilean Economic Development Agency (CORFO). The agency coordinated the technical assistance received from different agencies, facilitated funding as well as supervised and assessed performance. Another important tool used in Chile to develop new exports was the Fundación Chile, which was based on a private-public partnership. Its role was to help create and develop start-up companies with the help of venture capitalists in projects promoting technology transfers. Fundación Chile would eventually sell the invested company shares to keep pursuing new projects. Among its successes are the salmon and blueberries export industries, in which Chile is still highly competitive today. The state did not explicitly target specific sectors, and the industries that benefitted from different programs were mainly in the agro-industry (Varas 2013).

In the mid-2000s, a new inflection in the diversification strategy took place with the implementation of the National Strategy of Innovation for Competitiveness (NSIC). In the new strategy, the guiding principle of neutrality and focus on comparative advantage sectors were reiterated, and a study was conducted to identify these sectors. The study concluded that Chile's growth potential was in a set of 7 clusters, mainly in the agro-industry as well as tourism, logistics, communications, and transport. The target of state intervention would be to expand technical skills, improve productivity, and encourage innovation, especially in SMEs (Varas 2013).

Chile's success in terms of fighting poverty, real GDP growth and macro-stability is undeniable, but the country's productivity has lagged behind. Natural resource producers such as Malaysia, Mexico and Indonesia have outperformed Chile by a large margin in terms of export sophistication for the past two decades (Figure 7). More strikingly, Colombia's export sophistication overpassed Chile's in the late 1990s. An even starker statistic is Chile's total factor productivity that has not increased beyond its 1970 level (Figure 5) despite an increase in average years of schooling and manufacturing output per worker (Figures 6 and $8)$.

\section{The Pitfalls of Focusing on Services}

Examining sectoral shares of GDP of advanced economies and concluding that certain sectors are more important than others could be misleading. Non-tradables usually represent a big part of a country's GDP. Services also account for a large share of GDP, while manufacturing does not, especially in advanced countries. One may be tempted to invest and encourage services, especially since the recent evidence suggests that many developing countries have started switching to services at much earlier stages of development (Rodrik 2014). Yet, advanced economies at comparable stages of development as Malaysia today had larger shares of manufacturing and smaller shares of services. In addition, even though many emerging economies have GDP breakdowns broadly similar to those of advanced ones, their productivity in manufacturing (and in producing tradable goods in general) are much lower than that in advanced countries. Achieving high productivity gains is still more likely in manufacturing than services even in today's post-industrial age. 
In this respect, an overwhelming focus on services is not going to be helpful in generating high productivity gains the country needs to escape the middle-income trap. Developing tourism, logistics, transportation and financial services may result in output diversification, but are less conducive to sustained productivity gains. Although some of these services may generate employment, they rely mainly on low skilled labor (e.g. tourism and transportation) and would not support the development of high skills needed for the high-growth economy. As shown in Arezki et al. (2009), specialization in tourism yields limited growth benefits. For instance, an increase in the tourism sector share of exports by 8 percent (one standard deviation in a sample of more than 80 countries over 1980-1990) increases growth by only one-half percentage points a year. Focusing on high-value added services may not be sufficient to generate enough employment for new labor market entrants. Even the finance sector paying high wages is not enough to generate sufficient employment. London's finance and insurance sector directly employed less than 10 percent of workers in 2012. In addition, the amount of services exported is usually insufficient to cover imports. Net service balance in Malaysia has been negative since 1960 (except 2007-2009, which recorded a small surplus) despite the growth of exports.

The alternative combination of high valued-added manufacturing and services would be closer to Korea and Taiwan Province of China's growth strategies. In theory, high valueadded sectors and the associated high-wage jobs exist in both the tradable and non-tradable sectors. However, for an economy to generate a sufficient number of jobs in the high valueadded non-tradables (e.g. software, design, etc.) it needs to create a network of interlinked tradable and non-tradable sectors. A lot of advances in the information and communications technology (ICT) sector have spurred growth and productivity gains in manufacturing. Norway's oil cluster and services are linked to the oil industry manufacturing. Marketing services are closely connected to R\&D departments of manufacturing firms. A focus on services alone is not sufficient.

\section{CONCLUding Remarks}

Although persistent high productivity gains are key to sustainable growth, achieving these gains in practice is not easy. Many countries improved their relative income standing since 1970. Yet not many countries have grown from low-income status to middle-income status, and only a few countries have made it from the middle-income level to the high-income level. This paper defines the thresholds of the middle-income trap as the percentiles of relative income (to the United States) distribution. The $75^{\text {th }}$ percentile that defines the highincome threshold is 46 percent of the real income per capita in the United States, $\$ 19,050$ (2005 PPP terms) in 2010. With an average growth rate of about 2.8 percent per year, Malaysia has moved from 20 percent to 26 percent of the U.S. income per capita during the 1970-2010 period, far below from the high-income threshold. Malaysia has been stuck in the "middle-income trap" for the past four decades, and at that speed, it may take a long time to escape it. To address Malaysia's transition to high-income status, the government's new 
comprehensive reform plan under the Economic Transformation Program and the $10^{\text {th }}$ Malaysia Plan, is currently being implemented. However, it is too early to assess the results. ${ }^{17}$

Despite its relatively good growth performance, Malaysia's productivity gains lagged behind. Average schooling increased substantially, and other relevant economic indicators such as business climate, infrastructure, and openness to trade also improved. Manufacturing exports increased as oil exports dwindled. These exports, with the support of MNCs, mostly in the electronics sector, contributed to the large increase in export sophistication. Yet productivity gains did not materialize to achieve high growth rates.

The main difference between the growth model of Malaysia and Korea and Taiwan Province of China lies in its approach to technology adoption and creation. The Malaysian state tried hard to facilitate technology transfer and diffusion from MNCs, especially in the electronics sector, but the strategy did not yield significant results. MNCs contributed to export sophistication and upgrading but much less to technology diffusion. A few local firms were established by former MNCs' employees, and these firms grew relatively large. Nonetheless, Malaysia accounts for a small share of patents filed in the United States, while the country's R\&D spending is not large, especially compared to Korea's R\&D spending.

The experience of Taiwan Province of China and Korea illustrates the importance of local technology creation, spearheaded by the government. In various sectors, Korean and Taiwan Province of China firms endeavored in frontier technologies early on rather than moving along standard stages of development of imitating and then innovating. In Taiwan Province of China, the government intervened directly to create innovative firms through the spin-off system with the major role played by returnees that had the relevant experience and networks. This approach could work well for SMEs and firms in the global value chain. To create its system integrators or global brands, Korea pushed several chaebols (through monetary and other incentives) to enter several industries simultaneously (automotive, shipbuilding, electronics, etc.). The chaebols were strongly encouraged to export almost immediately and compete for resources amongst each other. Eventually, only a handful of chaebols remained within each industry.

High value-added tradable manufacturing and high-tech innovation sectors offer opportunities for local technology creation, high potential spillovers, and sustainable growth and employment. The state policy would most likely involve sectors that are far from comparative advantage, as the case of Chile illustrates. In addition, the services sector overall is not sufficient to provide sustained gains in productivity. Rather, the combination of high valued-added manufacturing and services, creating a network of interlinked high value-added tradable and non-tradable sectors, would be a sustainable growth strategy. Korea and Taiwan Province of China's examples show that the governments not only provided the enabling environment for innovation but they were directly involved in "creating winners" as the late Sanjaya Lall put it.

\footnotetext{
${ }^{17}$ The plans include improving the quality of education and increasing R\&D spending to boost innovation, which could spur local technology creation and sustainable productivity growth (see the IMF's 2014 Article IV Consultation-Staff Report: http://www.imf.org/external/pubs/cat/longres.aspx?sk=42761.0).
} 


\section{References}

Acemoglu, Daron, Philippe Aghion, and Fabrizio Zilibotti, 2006. "Distance to Frontier, Selection, and Economic Growth," Journal of the European Economic Association, 4(1): 37-74.

Agenor, Pierre-Richard and Otaviano Canuto, 2012. "Middle-Income Growth Traps," Policy Research Working Paper 6210, World Bank.

Aghion, Philippe, and Peter Howitt, 1992. "A Model of Growth Through Creative Destruction," Econometrica, 60: 323-351.

Aiyar, Shekhar, Romain Duval, Damien Puy, Yiqun Wu, and Longmei Zhang, 2013.

"Growth Slowdowns and the Middle-Income Trap," IMF Working Papers 13/71.

Arezki, Rabah, Reda Cherif, and John Piotrowski, 2009. "Tourism Specialization and Economic Development: Evidence from the UNESCO World Heritage List," IMF Working Paper 09/176.

Best, Michael, 2007. "Cluster Dynamics in Malaysian Electronics," in Jomo K. S. (ed.), Malaysian Industrial Policy, Singapore: National University of Singapore Press, 249276.

Bulman, David, Maya Eden, and Ha Nguyen, 2012. “Transitioning from Low-Income Growth to High-Income Growth: Is there a Middle-Income Trap?" World Bank, background paper for G-20 Meeting, June.

Caselli, Francesco, 2005, “Accounting for Income Differences Across Countries,” in Philippe Aghion and Steven Durlauf (eds.), Handbook of Economic Growth Volume 1A, New York: North-Holland, 679-741.

Chang, Ha-Joon, 2013. "Industrial Policy: From Ideology to Pragmatism," presentation at the World Bank conference on Making Growth Happen: Implementing Policies for Competitive Industries, October.

Chang, Ha-Joon and Justin Lin, 2009. "Should Industrial Policy in Developing Countries Conform to Comparative Advantage or Defy it? A Debate Between Justin Lin and Ha-Joon Chang," Development Policy Review, 27, September: 483-502.

Chen, Been-Lon, Yun-Peng Chu, and Tain-Jy Chen, 2001, "Rethinking the Development Paradigm: Lessons from Taiwan-The Optimal Degree of Government Intervention," in P.-K. Wong and C.-Y. Ng (eds.), Industrial Policy, Innovation and Economic Growth: The Experience of Japan and the Asian NIEs, Singapore: National Singapore University Press, 197-244.

Cherif, Reda and Fuad Hasanov, forthcoming. "Exports Sophistication, Investment and 
Growth,” IMF Working Paper.

Eichengreen, Barry, Donghyun Park, and Kwanho Shin, 2013. "Growth Slowdowns Redux: New Evidence on the Middle-Income Trap," NBER Working Paper No. 18673.

Felipe, Jesus, 2012. "Tracking the Middle-Income Trap: What is It, Who is in It, and Why? Part 1," Asian Development Bank Economics Working Paper Series No. 306.

Felker, Greg, 2001. "The Politics of Industrial Investment Policy Reform in Malaysia and Thailand," in Jomo K. S. (ed.), Southeast Asia's Industrialization: Industrial Policy, Capabilities and Sustainability, New York: Palgrave, 129-182.

Fuller, Douglas B., 2002, "Globalization for Nation Building: Industrial Policy for HighTechnology Products in Taiwan Province of China," MIT Japan Working Paper 02.02 .

Gerschenkron, Alexander, 1962. Economic Backwardness in Historical Perspective, Harvard University Press.

Greene, Megan J., 2008, The Origins of the Developmental State in Taiwan: Science Policy and the Quest for Modernization, Cambridge, Massachusetts: Harvard University Press.

Hausmann, Ricardo, Jason Hwang, and Dani Rodrik, 2007. "What You Export Matters," Journal of Economic Growth, 12(1), March: 1-25.

Hayakawa, Kazunobu, Fukunari Kimura, and Tomohiro Machikita, 2010. "Firm-level Analysis of Globalization: A Survey of the Eight Literatures," Economic Research Institute for ASEAN Discussion Paper Series.

Heum, Per, 2008. "Local Content Development - Experiences from Oil and Gas Activities in Norway," SNF Center for Applied Research at Norwegian School of Economics, Bergen.

Hong, Sung Gul, 1997, The Political Economy of Industrial Policy in East Asia: The Semiconductor Industry in Taiwan and South Korea, Cheltenham, England: Edward Elgar.

Jarreau, Joachim and Sandra Poncet, 2012. "Export Sophistication and Economic Growth: Evidence from China," Journal of Development Economics, 97(2): 281-292.

Javorcik, Beata, 2010. "Foreign Direct Investment and International Technology Transfer," prepared for the Encyclopedia of Financial Globalization.

Jomo, K. S., 2001. "Introduction: Growth and Structural Change in the Second-Tier 
Southeast Asian NICs," in Jomo K. S. (ed.), Southeast Asia's Industrialization: Industrial Policy, Capabilities and Sustainability, New York: Palgrave, 1-29.

Jomo K. S. with Chen Yun Chung, Brian Folk, Irfan ul-Haque, Pasuk Phongpaichit, Batara Simatupang, and Mayuri Tateishi, 1997. Southeast Asia's Misunderstood Miracle: Industrial Policy and Economic Development in Thailand, Malaysia, and Indonesia. Westview Press, Oxford.

Lee, Chung-Shing and Michael Pecht, 1997. The Taiwan Electronics Industry, The Electronics Industry Research Series, Boca Raton, Florida: CRC Press.

Leskinen, Olivia, Paul Klouman Bekken, Haja Razafinjatovo, and Manuel García, 2012. "Norway Oil and Gas Cluster: A Story of Achieving Success through Supplier Development," Harvard Business School.

Low, Linda, 2001. "The Role of the Government in Singapore's Industrialization," in Jomo K. S. (ed.), Southeast Asia's Industrialization: Industrial Policy, Capabilities and Sustainability, New York: Palgrave, 113-128.

Lucas, Robert Jr., 1993. “Making a Miracle,” Econometrica, 61(2), March: 251-272.

Ma, Hong, Zhi Wang, and Kunfu Zhu, 2013. "Domestic Value-added in China's Exports and its Distribution by Firm Ownership," US International Trade Commission Working Paper.

Mathews, John, 2006. “The 'how to' of Technological Change: The Case of Electronics in Taiwan" in Vandana Chandra (ed.), Technology, Adaptation and Exports: How Some Countries Got It Right, Washington, DC: World Bank, 83-126.

Moretti, Enrico, 2013. The New Geography of Jobs, New York: Houghton Mifflin Harcourt.

Ramírez, Carlos and Ling Hui Tan, 2004. "Singapore Inc. versus the Private Sector: Are Government-Linked Companies Different?” IMF Staff Papers, 51(3): 510-528.

Rasiah, Rajah, 2007. "R\&D and Export Intensities in Automotive Parts Firms in China, Malaysia, Philippines and Taiwan: Does Ownership Matter?" RIETI Discussion Paper Series.

Rasiah, Rajah, 2004. "Foreign Ownership, Technological Intensities, and Network Strengths: Electronics Firms in East Asia," OECD conference paper on The Impact and Coherence of OECD Country Policies on Asian Developing Economies.

Rasiah, Rajah, 2001. "Southeast Asia's Ersatz Miracle: The Dubious Sustainability of its Growth and Industrialization," in Jomo K. S. (ed.), Southeast Asia's Industrialization: Industrial Policy, Capabilities and Sustainability, New York: Palgrave, 86-112. 
Rodrik, Dani, 2014. "New Growth Strategies," presentation at the World Bank conference on New Growth Strategies: Delivering on their Promise? October.

Rodrik, Dani, 2005. "Growth Strategies," in Philippe Aghion \& Steven Durlauf (ed.), Handbook of Economic Growth, edition 1, volume 1, chapter 14, Oxford: Elsevier, 967-1014.

Sasson, Amir and Atle Blomgren, 2011a. "Knowledge Based Oil and Gas Industry," Knowledge-based Norway, March, Report No. 4.

Sasson, Amir and Atle Blomgren, 2011b. "Developing NODE: Mediating Strategy for Sustainable Growth,” Working Paper, Oslo: Norwegian Business School, December.

Saxenian, AnnaLee and Jinn Yuh Hsu, 2001. "The Silicon Valley-Hsinchu Connection: Technical Communities and Industrial Upgrading," Industrial and Corporate Change, 10(4): 893-920.

Saxenian, AnnaLee, 2001. "Taiwan's Hsinchu Region: Imitator and Partner for Silicon Valley," Stanford Institute for Economic Policy Research Discussion Paper No. 0044.

Smart, Alan and Josephine Smart, 2005. Petty Capitalists and Globalization: Flexibility, Entrepreneurship, and Economic Development, Albany: SUNY Press.

Smeets, Roger, 2008. "Collecting the Pieces of the FDI Knowledge Spillovers Puzzle," World Bank Research Observer, 23(2): 107-138.

Steers, Richard M., 1999. Made in Korea: Chung Ju Yung and the Rise of Hyundai, London: Routledge.

Sun, Xiaonan and Junjie Hong, 2011. "Exports, Ownership and Firm Productivity: Evidence from China," World Economy, 34(7): 1199-1215.

Tran, Van Tho, 2013. "The Middle-Income Trap: Issues for Members of the Association of Southeast Asian Nations," Asian Development Bank Institute Working Paper 421.

Varas, Maria Elena, 2012. "Economic Diversification: The Case of Chile," Revenue Watch Institute.

Woo, Meredith Jung-en, 1991. Race to the Swift: State and Finance in Korean Industrialization, New York: Columbia University Press.

World Bank and the Development Research Center of the State Council, P. R. China, 2013. China 2030: Building a Modern, Harmonious, and Creative Society, Washington, DC, World Bank. 